\title{
An Experience on the Integration of ICT into a Teaching-learning Methodology of English as a Foreign Language
}

\author{
Roberto Martínez Mateo \\ Department of Modern Philology, University of Castile La-Mancha, Cuenca, Spain \\ Email: Roberto.Martinez@uclm.es
}

\begin{abstract}
In this paper, we present the use of free ICT materials to foster the communicative approach in an actual educational setting. Specifically, we show and discuss the outcomes of the exploitation of two websites' content and resources inserted in our subject curriculum. This initiative has been put forward to work on listening skills as a means for attaining a twofold objective: i) as the first step to favour communication from the addressee's stance by further building their ability to recognize and reproduce Anglophone pronunciation and, ii) secondly, to encourage self-learning through an Internet-based resource. Although it is widely recognised that in Foreign Language Teaching (FLT) a common agreement has not yet been reached on what methodology is the ideal for every possible linguistic learning situation, it seems that there is general consensus within the teachers of English as a Foreign Language (EFL) community to bestow value on the Communicative Approach. Under the European Higher Education Area (EHEA) framework, the notion of "competence" (Hymes, 1972) has gained momentum in the teaching arena. Faced with this simultaneous responsibility and opportunity that the EHEA has brought about, we advocate the gradual integration of technology for language learning (CALL) to develop a functional communicative competence.
\end{abstract}

Index Terms - planning and expected outcomes, implementation, real effects, discussion

\section{INTRODUCTION}

Traditionally, foreign language instruction in Spain has heavily relied on the methodologies that viewed language as a system or a structure. Amongst these methods we find Grammar-Translation, Audiolingualism or Situational Language Teaching, to cite but a few. In spite of the advantages and the virtues they offered at the time of their appearance now, in hindsight, we consider these teaching methodologies to have constituted a hindrance in the development of the oral auditory language skills of pupils, especially for English as a foreign language (EFL). Following Palacios (1999), we believe that the progresses made in linguistic theorising have left their trace in foreign language didactics. In fact, the enormous impact that the various linguistic theories have exerted on foreign language teaching is undeniable. As a result, at the end of the twentieth century, the eagerness to overcome the communicative restraints of previous linguistics models meant a turning point in language conception.

In the $60 \mathrm{~s}$ and $70 \mathrm{~s}$, British language teaching tradition, as a critique to the previous structural and behaviourist methodologies, originated a new methodology supported by scholars like Henry Widdowson and Christopher Candlin, who followed the theories of John Firth and and Halliday's functional linguistics and of Dell Hymes' socio-linguistics. This view considered language as a vehicle for the expression of values and judgements, placing special emphasis on the communicative dimension of language over its grammatical features. These ideas translated into a language teaching methodology known as the Communicative Approach (CA) or the Communicative Language Teaching (CLT). Amongst the main objectives pursued by the Communicative Language Teaching (CLT) approach, two stand out:

1. Firstly, to attain communicative efficiency and,

2. Secondly, to place learner in the centre of learning process.

From then onwards, the communicative features of language have come to the foreground in foreign language studies and consequently, the functional component of language has been stressed (Martínez Agudo, 2006: 16). This has led to a change of point of view in foreign language teaching: the realization that language has to be studied contextualized and considering the communicative intentions of users. Thus, language is now seen as an interactional activity where communicative purposes prevail over structure, and its analysis can only take place within discourse.

Language being thus considered, the main goal sought in FLT for some decades now is the communicative competence of learners. Drawing on the initial definition of communicative competence provided by Hymes (1972), subsequently modified by Canale \& Swain (1980) and Canale (1983), we share the final adjustments introduced by Celce-Murcia (1995, 2000), which specified that "the various components of communicative competence were interrelated and that it was important to properly describe the nature of these interrelationships in order to fully understand the construct of communicative competence" (Celce-Murcia, 2008: 44). In Celce-Murcia's model of communicative competence, the core feature is precisely discourse competence. This central subcompetence interfaces 
with the linguistic, sociolinguistic and actional subcompetences to shape discourse and, in turn, all three subcompetences resort to a fourth, the strategic one, when they encounter any deficiency. "The goal should be for learners to interpret and produce meaningful discourse yet also to practice the phonological features, words, formulas, and grammatical structures that are salient in the discourse providing the content" (Celce-Murcia, 2008: 51).

The aforementioned goal may seem appropriate for designing a general course curriculum starting from scratch; however, we deem it is necessary to identify the specific linguistic and communicative demands of the target situations (deficiencies of the learners) as a basis for focused course development.

As is written in the Preamble to the Berlin Communiqué (Berlin Communiqué, 2003), the main objective of the Bologna process was "the development of a coherent and cohesive European Higher Education Area by 2010". This space, recently implemented (2010-11 academic year), has stirred a profound re-conceptualization of tertiary education in Spain that has translated into curricular rearrangement. Amongst its more prominent implications, mainly due to the novel design and conception of credits (ECTS), we are witnessing a drastic shift in the duties of the actors involved in the teaching-leaning process. As Pérez Cañado (2010: 103) puts it, "the EHEA is subverting the roles of students and teachers in tertiary language education".

Hence, within the framework of an Educational and Teaching Course for Innovation completed at my home university (UCLM), we planned and put into practice $\left(2^{\text {nd }}\right.$ term of 2009-10) an improvement project during a one-term subject to redress a detected deficiency in oral communicative competence. In our proposal, focused on interaction and self-study as the means and on effective communication as the goal, we reckon that ICT exploitation for teaching purposes may serve a purpose in developing the Oral Auditory Communicative Competence (OACC).

\section{INITIAL PICTURE}

The acquisition of an adequate oral communicative competence (OCC) in at least one foreign language constitutes one of the European educational systems' main challenges for this new century. Nevertheless, a widespread worry exists that, despite the relevance given nowadays to the fact of being fluent in more than one European Community language, students don't achieve satisfactory levels of competence in foreign languages at the completion of compulsory education. (Martínez Piñeiro, 2002)

This quotation draws the portrait of the students' profile after completing their compulsory secondary education in a particular region of Spain, Galicia, and it describes quite rightly the context we were faced with. We present, in this paper, an experience undertaken with sophomore students in the degree on Humanities of the University of Castilla-La Mancha (Faculty of EE. SS. and Humanities, Cuenca). The subject under study is English II, a purely instrumental subject within the degree. This 7.5-credit core subject is taught in the second year and intends to provide students with ample language practice. It aims to help students to improve their communicative competence (oral or in writing) and to enable them to read and write fluently in the foreign language.

The spark that motivated this initiative was a deficiency detected in the very same group that was in our hands in the previous academic year. The initial objective data that confirmed and triggered this initiative were the poor performances that these freshmen showed on their first evaluation of English skills. From twenty-three students enrolled in the course, three of them did not sit for the final test, so they were not evaluated. The rest of the class regularly attended face-to-face tuition and submitted the assignments requested in the continuous assessment, so they fulfilled the ECTS requirements. Therefore, they could take the final exam and were marked accordingly. The grades, on a 1-10 scale, were distributed as follows: five scored between 7 and 8.5 points; ten between 5 and 6 points and five failed the exam with a grade between 3 and 4.9 points, giving an average grade of 5.5 .

A deeper look into the performance of this (at the time of assessment) freshmen group showed that there was a marked imbalance between the grades they got on the writing and reading skills and the ones they obtained in listening and speaking ones. On the whole, they presented a much worse level of attainment in the latter. Although they were mostly able to read general and semi-specialized texts and to write acceptably, their oral auditory communicative competence obtained low scores. This is not something new. On the contrary, we find dozens of articles quoting recurrently this deficit in the specialized EFL literature. So, to begin with, we needed to "analyse the student's needs, face their problems and find fruitful solutions that help them to develop their speaking abilities" (Navarro Romero, 2009). Besides, apart from pinpointing the exact weaknesses of our pupils, we have to be cognizant that we always have to work within limited hour allocation and resource availability, bearing in mind that "language teachers and learners operate within a set of interrelated constraints. These constraints, often associated with the limited time and resources available to the teacher and the student, typically include the number of contact hours pre-determined for a course, lesson times and durations, technical support, ancillary learning materials, and so on" (Hubbard \& Levy, 2006: 8).

Consequently, our aim was to provide learners with self-study strategies and resources that they might use outside the class to cater for their specific weaknesses and which could complement ordinary face-to-face EFL (Godeo, 2002-2003: 114). As a result, a new method was devised and inserted in our curriculum as an innovation project to make the most of the computer room using it as a language laboratory.

\section{PRoPOSAL PLANNING AND EXPECTED OUTCOMES}


Communicative Language Teaching (CLT) (in comparison with previous methods) and the recent implementation of the ECTS within the framework of EHEA have considerably modified the long-established roles of teacher and pupils in FLT. Whereas the teacher must slacken the reins a bit to play a different part in relation to students, these, in turn, have been pushed to assume a more active role in their learning process.

Thus, quite in agreement with present EHEA tenets, teachers are to act more as facilitators, organizers, motivators, counsellors, analysts than as the traditional directors, orchestrators or instructors (Pérez Cañado, 2010: 105) of the class. Hence, the teacher's role should be less controlling and should give way to a more flexible position from where the teacher may be ready to organize resources, act as a guide or even as a participant in the activity, or whatever the situation may require. Nonetheless, his main function will be to act as a communication activator. Conversely, students have to be active and participate in their learning process. Their involvement in the learning process has always been very important and, under this new instruction concept, it turns out to be essential.

Thus, our intention was to delve deeper into a student-oriented task-based approach rather than using the traditional text-based teacher-oriented one. This paper wants to present a humble experience on the integration, in a Higher Education context, of opportunities for learning with computers (Computer Assisted Language Learning, CALL) coexisting with opportunities for learning face-to-face (Jager, 2009: 32), since, as Jager (2009: 19) claims: "The potential of CALL is thus not utilised to the full, both in terms of the number of regular users and in terms of the kinds of applications used".

In order to deploy this initiative, we decided to explore a CALL methodology, focusing on the exploitation of a free website. As regards CALL, we will adhere to the definition provided by Hubbard (2009: 1), who characterizes it as "any process in which the learner uses a computer and, as a result, improves his or her own language". Although it is a broad definition, as Hubbard himself admitted (2009: 1), he also argued that it is a "reasonable starting point". He goes further defining the concept of "computer" as not "simply the canonical desktop and laptop devices" (Hubbard, 2009:1) but including also all technological innovations such as PDAs, mp3/mp4 players, mobile phones, electronic whiteboards and even DVD players (Hubbard, 2009: 2).

Nonetheless, we wanted to achieve this curricular insertion seamlessly, in other words, without disrupting the real objective of the course, but facilitating the means. We tried to avoid the fact that students may be distracted with the introduction of any sort of technology just for the sake of it. Our general purpose was to employ ICT, firstly, to exercise the listening and speaking skills in class to reinforce students' abilities and consequently students' confidence to speak, and, secondly, to foster the opportunity of practising anywhere and anytime, with the help of an Internet connected terminal (notebook, laptop or other electronic device), an mp3/mp3 player or the like. From the curricular point of view, we planned and inserted this laboratory session into the weekly schedule so that we could reach "a stage where technology becomes invisible, embedded in everyday practice and hence normalised" (Bax, 2003: 23).

We fully share the following quotation: "Hay que tener presente que el aula de lengua extranjera supone un espacio de interacción y comunicación que ha de ofrecer múltiples posibilidades de expresión oral” (Martínez Agudo, 2003). ${ }^{1}$ Besides, we wanted to extend this interactional and communication atmosphere from a functional approach to the computer room, our language laboratory. During the laboratory session programmed on Thursdays, we wanted to test our hypothesis: we postulated that, in many cases, the low performance in the speaking and listening skills in Spanish students of EFL was due to a lack of understanding of Anglo-Saxon sounds. It is reasonable to assume that to the ears of a Spanish speaker who learns English, the origin of the difficulty partly lies in the very nature of Anglo-Saxon sounds, many of which are unknown to them because they do not belong to their phonological spectrum. Precisely therein lies much of the complexity for them to recognise and imitate these sounds.

What is more, that drawback severely undermines the possibility of communication to take place, especially when the interlocutor is a native English speaker or has a native-like pronunciation. Missing some chunks of a dialogue prevents effective oral messages from getting through. It is important to emphasize this fact because such a problem is not so evident when the communicative act takes place between a Spanish speaker of English and another non-native English speaker. Nonetheless, the more similar the interlocutor's pronunciation is to that of a native speaker, the more difficult it is for communication to carry on. This hurdle cannot be attributed to a single reason, but it seems plausible to think that it might be due to the lack of equivalence between the sounds of English and Spanish. Moreover, it has to be noted that traditionally, much less time and funding have been devoted to the speaking and listening skills within the Spanish educational system if compared with the grammatical skills (reading and writing).

As a consequence, it is not uncommon to ascertain that Spanish speakers of English are clearly disadvantaged in this sense in comparison to students from other European countries whose educational system has accorded greater weight to the oral communicative skills.

Our primary intention with this initiative was to improve students' capability to recognize and reproduce Anglophone pronunciation as an initial step towards fostering oral communicative competence and, secondly, to encourage selflearning through an Internet-based resource. So, unquestionably, some phonetics instruction was needed. Indeed, what we were looking for was an ad-hoc crash course on phonetics that may be fitted into the time and resource restrictions

\footnotetext{
"We have to be aware that foreign language class is an interactional and communicative space that offers multiple opportunities for oral practice" (our translation).
} 
of our subjects and may serve its purpose: to provide the basics to build upon. At the same time, students needed to be provided with as many oral auditory interaction opportunities as possible within and outside the class, and the CALL approach provided us with the tools to do so. A task-based (Nunan, 2004: 1) approach was followed and, simultaneously, self-study and life-long learning were promoted. The experience also sought to enable "learners to draw upon the language laboratory to develop autonomous work as a supplement to conventional group class work" (Godeo, 2002-2003: 114).

After some sifting, trying and testing a considerable amount of on line free resources, we selected the website to use in our laboratory sessions: BBC Learning English. ${ }^{2}$ This is a BBC (British Broadcasting Corporation) owned and controlled site, whose contents can be copied, broadcast, downloaded, stored (in any medium), transmitted, showed or played for educational purposes. And this is exactly what we got. In line with Robin (2007: 109) in Hubbard (2009: 6), "in the immediate future - the next five to ten years- the frontier in language learning and technology will not be found in what program does what better, but rather which students use off-the-shelf technology to best facilitate their own learning in their own learning style".

Theoretically, the chosen website fulfilled the criteria stated by Hubbard (2009: 2) as requisites to contribute to "improve the language", since it helps learners to "pick skills" faster and "retain" them longer. It adds "convenience" of usage by widening the range of times and places. Freshmen and sophomores seem to be easily "engaged in the learning process" by using technological devices, and this free site was "used as it is, without needing any customization" on behalf of the teacher (2009: 2).

\section{IMPLEMENTATION}

The execution and implementation of this experience was easily inserted into the course dynamics. It was conducted on Thursdays, in one-hour sessions in the computer lab. Students only had to bring their own headphones to work independently on the terminals. This allowed us to attain two intermediate goals. In the first place, by listening individually to the recordings, the students were able to work at their own personal pace and, secondly, they were able to work in a more focused way by eliminating background noise. Since no two students are the same, customized teaching techniques may certainly facilitate working at their own rhythm. The site offered a wealth of valuable resources, which is why we had to choose the ones that best fit our aims within the course constrains. The tabs selected to work on in this website consist basically of recordings that the user has to listen to in order to complete a series of exercises on them, with the user being in control of the activities. The student has to click on the buttons to play the excerpt, to pause it, to repeat it; everything at his own discretion. Sometimes a student needs to stop a listening to process a piece of information or to replay an extract to fully grasp its meaning - a simple procedure that proves highly convenient and intuitive for students of the era of technology.

Under close monitoring, we worked through a phonetics course that can be practiced in tab Pronunciation Tips ${ }^{3}$, where one can find the complete phonetics chart of English sounds. What attracted us most and made us opt for this site was its user-friendliness and intuitiveness. Above all, I liked the way phonetics is presented to the learner in this page. Once a selection is made, a window pops up where a video is played. In this video, the user is shown how to follow the course, so that there is a visual and auditory explanation of the method. The link comprises five tabs. In the first tab (Introduction), we are provided with a short introduction to the course procedure. The second one (The Sounds of English) contains a chart with all the English sounds where the user has to click on a sound symbol to obatin a pop up window with an explanatory video. The student sees and hears how to pronounce the sounds. Besides, the users can also download these videos or a $p d f$ file with examples, along with their phonetic transcription. These short videos (just over a long) provide a practical, easy to use and convenient solution to work on phonetics according to the students' needs, pace and availability. Therefore, the learners can practice naturally the linguistic features they need to acquire (Goodwin, 2001: 118): intonation, rhythm, reduced speech, linking words, consonants and vowel sounds, or word stress, almost without realising it. The fourth tab (Quizzes) contains several practice tests and on the last tab (Programmes), three radio programmes produced by the BBC in 2005 can be downloaded. These three downloads are on the weak form of schwa, consonant to vowel linking and vowel to vowel linking, respectively.

Within the same website, another tab was chosen to complement the OACC practise: the one under the title Welcome To London. ${ }^{4}$ This is a content-oriented site where hand in hand with two characters, Fiona and John, we go through a series of real-life situations as they arrive and settle down in the city. It is an intermediate language level that allows the user to exercise English skills with a task-based language teaching (TBLT) (Nunan 2004: 1) approach. Most of the activities worked upon start with a listening (and some with an introductory text). Once the student plays the recording (or reads the text), he has to complete the dialogue by dragging and dropping the lines in the right order (or completing a multiple choice exercise). Two language tips accompany all these tasks: one on a Grammar Feature and another one on Vocabulary that comes up in the extract. Later, the students, working in pairs, are asked to act out orally the situation

\footnotetext{
${ }^{2}$ It can be found on the link: http://www.bbc.co.uk/worldservice/learningenglish/ (accessed 20/1/2010).

${ }^{3}$ It can be found on the link: http://www.bbc.co.uk/worldservice/learningenglish/grammar/pron/ (accessed 10/2/2010).

${ }^{4}$ Website: http://www.bbc.co.uk/worldservice/learningenglish/multimedia/london/ (accessed 2/2/2010).
} 
reproducing as much content as possible. In a second rehearsal, they are requires to introduce new data. Finally, they are asked to improvise a dialogue, departing from the structure provided. The proposed model for our tuition is thus a PPP (presentation, practice, production), TTT (testing, teaching and testing) or MMM (meeting new language, manipulating it and making it your own) one, no matter what terminology is used to refer to this pattern for language teaching (Moya Guijarro et al., 2006: 12). Therefore, students are firstly presented with a guided exercise, later they are asked to perform a semi-guided role-play and finally they have to draw on this scaffolding to produce their own dialogue.

Consequently, in our daily routine primacy is given to oral work. In these interactions, errors are not systematically corrected, since they are considered part of the usual way of learning a language. By means of pre-arranged tasks, students are given the chance to perform a real-life situation in which language is the key to communicate. Authentic or semi-authentic materials are used in order to recreate as far as possible real-life situations and contexts. This way, students are encouraged to take an active part in a meaningful situation that could well take place in a real scenario (a trip to London). They feel that they are learning useful and meaningful strategies, formulae and linguistic resources to deploy outside the academic setting. Due to the familiarity with the topic at hand and the ICT usage, they are motivated to engage in the learning process. Unconsciously, they acquire grammar by using it in context, so it is easier and more entertaining. Nevertheless, communicative competence acquisition is the underlying and ultimate goal.

\section{REAL EFFECTS AND DISCUSSION}

To begin with, I would like to thank all the students who willingly accepted to take part and allowed their assessments to be used in this small-scale study. Personal data of students are not disclosed for confidentiality reasons. We wanted to measure and quantify the effects of our experience, if any. Our intention was to bestow as much objectivity as possible to the assessment process, in language evaluation task where the human factor cannot be discarded.

Given that the skills primarily worked on in this initiative were the oral and listening ones, in our verification phase we wanted to keep the students' performances for the record. The chosen method to check level of attainment was a tenminute personal interview with the teacher. Half the time was devoted to answering general questions and the other half was dedicated to a short dialogue on one of the topics that had been worked on in the website. To record the interviews we used a sound record software called Audacity 1.3 Beta (Unicode) that can be downloaded for free from several websites. In our case, the download was made from Softonic. ${ }^{5}$

The performance in the interviews was assessed based on the following four items made known to the students beforehand:

TABLE 1.

ASSESSMENT

\begin{tabular}{|l|l|l|}
\hline Item & Description & Assessment scale \\
\hline 1 & General objective assessment & $1-10$ scale \\
\hline 2 & $\begin{array}{l}\text { Overall improvement, if any, } \\
\text { regarding the starting point }\end{array}$ & $1-5$ scale $^{6}$ \\
\hline 3 & Improvement in listening skill & $1-5$ scale \\
\hline 4 & Improvement in speaking skill & $1-5$ scale \\
\hline
\end{tabular}

The study used a non-probability incidental sampling (Aliaga, 2000). Thirteen students took the oral test in the second term final exam, so this is the number of the final sample. The results were classified according to the four items described above:

- The average grade in item 1 was 6.38 , somewhat higher than the 5.5 average grade that the core of the group had scored in the previous course.

- Item 2 offered an average of 2.69, which implies that overall improvement is between poor and some improvement, tending towards the latter.

- Item 3 showed a significant leap with a mean value of 3.

- Lastly, item 4 scored a mean value of 2.15, what translates into a poor improvement in speaking skill.

None of the four items analyzed showed a great improvement, although three of them registered a moderate increase. Amongst these, it is worth noticing that there is an outstanding improvement in oral comprehension. Undoubtedly, this was the skill to which most time was devoted in the laboratory sessions; therefore, we were somewhat reassured because our proposal seemed to pay off. The low performance registered in item 4 , as compared to item 3, can perhaps be ascribed to the longer time span it takes to attain good results in the speaking skill. Sound recognition enhancement comes first in the improvement process and will subsequently lead to a gain in speaking ability.

Besides, the results of this computer-assisted learning experience reveal an improvement in motivation, academic performance and the development of social and communication skills (Salmerón-Pérez et. al., 2010), which encourages us to further apply this initiative to a larger sample and over a longer period in the future.

\footnotetext{
${ }^{5}$ Softonic website: http://www.softonic.com/ (accessed 4/3/2010).

${ }^{6}$ On a scale of 1 to 5, 1 means none, 2 means poor, 3 means some, 4 means quite and 5 equals great improvement in relation to the initial picture.
} 


\section{REFERENCES}

[1] Aliaga, F. (2000). Bases epistemológicas y proceso de investigación psicoeducativa. Valencia: C.S.V.

[2] Bax, S. (2003). CALL - Past, Present and Future. System 31, 13-28. http://www.sciencedirect.com/science?_ob=ArticleURL\&_udi=B6VCH-47PG7DT-

$3 \&$ _user $=1535769$ \&_coverDate $=03 \% 2 \mathrm{~F} 31 \% 2 \mathrm{~F} 2003 \&$ rdoc $=1 \&$ fmt $=$ high \&_orig $=$ search $\&$ origin $=$ search \&_sort=d\&_docanc hor=\&view=c\&_searchStrId=1619000674\&_rerunOrigin=google\&_acct=C000053616\&_version=1\&_urlVersion=0\&_userid= 1535769\&md5=e8925a202bfe146129a5b5069ffc06ce\&searchtype $=\mathrm{a}($ accessed 10/10/2010).

[3] Berlin Communiqué. http://www.bologna-berlin2003.de/en/main_documents/index.htm (accessed 8/9/2010).

[4] Celce-Murcia, M. (2008). Rethinking the role of communicative competence in language teaching. In Alcón Soler \& Safont Jordà (eds.), Intercultural language use and language learning. Oxford/Cambridge: Oxford University Press/Cambridge University Press, 41-57.

[5] Godeo, E. G. (2002-2003). Self-access and the multimedia language laboratory: Designing a resource centre for EFL university students. Encuentro. Journal of Research and Innovation in the Language Classroom $13 \quad \& \quad 14$. http://encuentrojournal.org/textcit.php?textdisplay=350 (accessed 5/8/2010).

[6] Goodwin, J. (2001). Teaching pronunciation. In M. Celce-Murcia (ed.), Teaching English as a second or foreign language. Boston. Heinle and Heinle.

[7] Hubbard, P. (ed.) (2009). Computer assisted language learning: Critical concepts in linguistics (4 vols.). London \& New York: Routledge.

[8] Hubbard, P. \& M. Levy. (2006). The scope of CALL education. In P. Hubbard \& M. Levy (eds.), Teacher education in CALL. Amsterdam: John Benjamins, 2-20.

[9] Hymes, D. (1972). On communicative competence. In J. B. Pride \& J. Holmes (eds.), Sociolinguistics: Selected readings. Harmondsworth: Penguin, 269-293.

[10] Jager, S. (2009). Towards ICT-integrated language learning: Developing an implementation framework in terms of pedagogy, technology and environment. Ph.D. dissertation, University of Groningen, Netherlands.

[11] Krashen, S. D. (1987). Principles and practice in second language acquisition. Hertforshire: Prentice Hall International.

[12] Krashen, S. D. \& T. Terrel. (1983). The natural approach. Pergamon.

[13] Lightbown \& Spada. (2006). How languages are learned. Oxford: Oxford University Press.

[14] Martínez Agudo, J. D. (2003). Hacia una enseñanza de lenguas extranjeras basada en el desarrollo de la interacción comunicativa. Didáctica (Lengua y Literatura)15, 139-160.

[15] Martínez Agudo, J. D. (2006). Uso comunicativo de las lenguas extranjeras. Grupo Editorial Universitario.

[16] Martínez Piñeiro, E. (2002). Oral communicative competence in English language at the completion of compulsory education. Level of achievement and conception of Galician community students. CAUCE, Revista de Filología y su Didáctica 25, 533561.

[17] Moya Guijarro, A. J., J. I. Albentosa, C. Harris (eds.) (2006). La enseñanza de las lenguas extranjeras en el marco europeo/The teaching and learning of foreign languages within the European framework. Cuenca: Servicio de Publicaciones de la Universidad de Castilla-La Mancha.

[18] Navarro Romero, B. (2009). Improving speaking skills. Encuentro. Journal of Research and Innovation in the Language Classroom 18. http://encuentrojournal.org/textcit.php?textdisplay=411 (accessed 20/10/2010).

[19] Nunan, D. (2004). Task-based language teaching. Cambridge: Cambridge University Press.

[20] Palacios, I. M. (1999). El desarrollo de la competencia comunicativa a través de la enseñanza de la gramática. In M. S. Salaberri (ed.), Lingüística aplicada a la enseñanza de las lenguas extranjeras. Servicio de Publicaciones de la Universidad de Almería, 479-530.

[21] Pérez Cañado, M. L. (2009). The European credit transfer system: Enhancing creativity in teachers and students. Humanising Language Teaching 11.1. http://www.hltmag.co.uk/feb09/mart03.htm (accessed 5/7/2010).

[22] Pérez Cañado, M. L. (2010). The transformation of teacher and student roles in the European higher education area. Journal of Language Teaching and Research 1.2, 103-110.

[23] Robin, R. (2007). Commentary: Learner-based listening and technological authenticity. Language Learning \& Technology 11.1, 109-115.

[24] Salmerón Pérez, H., S. Rodríguez Fernández \& C. Gutiérrez Braojos. (2010). Metodologías que optimizan la comunicación en entornos de aprendizaje virtual [Methodologies to improve communication in virtual learning environments]. Comunicar 34, 163-171.

Roberto Martínez Mateo received his M.A. in English Philology from the Basque Country University (Vitoria, Spain) in 1997. Later he earned his M.A in Translation and Interpreting from the University of Valladolid in 2000, where he worked as Associate teacher during 2003-04 academic course. At present he is a Teaching Assistant at the Modern Language Department at the Faculty of Education Sciences and Humanities of Universidad de Castilla-La Mancha, Cuenca Campus. He has been teaching in this University since 2005. He has worked as an in-house translator in a Madrid-based agency (July 2000-June 2002) and as a freelancer (July 2002September 2010), when he quit freelancing to devote his full attention to academic matters. His fields of study are new methodologies applied to FLT and Translation Quality Assessment (TQA) with a special focus on TQA metrics. 